\title{
Scientific misconduct and breach of publication ethics
}

\author{
Robert B. Daroff, MD; and Robert C. Griggs, MD
}

Journals occasionally receive notification or allegations of scientific misconduct or breach of publication ethics. Sparked by recent high profile cases, institutions receiving federal funds must have investigatory policies and procedures to deal with faculty scientific misconduct. ${ }^{1-3}$ Journals, editors, and editorial boards are not investigational bodies. As stated by Stephen P. Lock, Editor Emeritus of the British Medical Journal, at a 1990 Office of Scientific Integrity Workshop: "We are the JCI (referring to the Journal of Clinical Investigation), not the FBI."

Scientific misconduct includes "fabrication, falsification, and plagiarism," and requires an "intent to deceive" by the authors. ${ }^{3}$ The AMA Manual of Style 4 defines each of those terms, and separates out "omission" (defined as not presenting information that results in a distortion of truth) from the fabrication category. Honest error or differences in interpretation are not considered misconduct.

When Neurology suspects or receives an allegation of misconduct, we will notify the corresponding author's institution (Dean and President), copying the funding agency when applicable. Also, when applicable, we will copy an authorized investigative agency: the Office of Research Integrity for studies funded by the Public Health Service (NIH or other PHS entities), the Offices of Inspectors General of the National Science Foundation or Department of Veterans Affairs, or private agencies. Neurology will not notify the authors unless the allegation is plagiarism of another's written product. With fabrication and falsification, the institutions have the responsibility of notifying the authors. ${ }^{3}$

Consequences of misconduct. If Neurology identifies misconduct prior to publication, we will reject the manuscript, notify the previously mentioned institutions and agencies, and sanction the authors by not permitting them to submit papers to us for a specified length of time.

If an institution or investigative agency notifies us of misconduct involving a published article, we will retract the article in the form recommended by the International Committee of Medical Journal Edi- tors, ${ }^{5}$ as occurred on two occasions during the 1987 1996 term of Neurology's Editor-in-Chief. ${ }^{6,7}$ If there is credible evidence of misconduct, but it is insufficient to warrant a recommendation of retraction, Neurology may publish an "expression of concern," with an explanation. Prior to publishing a retraction or expression of concern, Neurology will notify the author, institution, investigative agency, funding agency, and Library of Congress (to correct the electronic version of the article). We will not publish any explanation by the authors without a reply rebuttal by the institution or agency that performed the investigation.

Breach of publication ethics. These include failure to reveal financial conflicts of interest; redundant (also called fragmented, prior, dual, double, duplicate, or repetitive) publications ${ }^{5,8}$; omitting a deserving author or adding a noncontributing author; misrepresenting publication status in the references (erroneously claiming that a paper is "in press"); and self-plagiarism without attribution.

In addition to possible sanctions, described above, and notification of the institutions and funding agencies, Neurology may take the following actions for these breaches:

Failure to reveal a financial conflict of interest will result in our publishing a "failure to disclose" that cites the omission.

Redundant publication will result in notification of the other journal, and retraction of the second article, if it has been published.

Omitting a deserving author or including a noncontributing author will require investigation by the authors' institutions. Neurology will notify them of the allegation, and await their investigation. If the institution advises us that a deserving author was omitted or a noncontributing author was included in a published article, we will acknowledge the breach in an erratum, and advise the National Library of Medicine to correct the electronic versions of the publication.

Misrepresenting publication status may result in

From Department of Neurology, Case Western Reserve University School of Medicine.

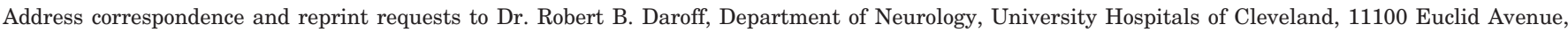
Cleveland, $\mathrm{OH}$ 44106; e-mail: robert.daroff@case.edu 
rejection of an unpublished manuscript, if the breach is deemed substantive.

Self-plagiarism without attribution is a copyright violation. Neurology will notify the holder of the original copyright.

Dealing with misconduct and ethical breaches is time-consuming and distracting for the Editor-inChief. For that reason, Neurology has created a position of Scientific Integrity Advisor to handle these issues. I, the former Editor-in-Chief of Neurology and a member of the Council of Science Editors and the World Association of Medical Editors, will be the journal's first Scientific Integrity Advisor.

We have incorporated our misconduct policies in our Information for Authors (available at http:// www.neurology.org).

\section{References}

1. Parrish DM. Scientific misconduct in correcting the scientific literature. Acad Med 1999;74:221-230.

2. Gunsalus CK. Scientific misconduct: policy issues. In: Jones AH, McLellan F, eds. Ethical issues in biomedical publication. Baltimore: The Johns Hopkins University Press, 2000:223-249.

3. Mello MM, Brennan TA. Due process in investigations of research misconduct. N Engl J Med 2003;349:1280-1286.

4. Iverson C, Flanagin A, Fontanarosa PB, et al. American Medical Association manual of style, 9th ed. Baltimore: Williams \& Wilkins, 1998.

5. International Committee of Medical Journal Editors. Uniform requirements for manuscripts submitted to biomedical journals, November 2003. Available at: http://www.icmje.org.

6. Stahl SM, Faull KF, Barchas JD, Berger PA. Cerebrospinal fluid monoamine metabolites in Huntington dementia, movement disorders, and normal aging. Neurology 1989;39:1261 [RETRACTION].

7. Abbs JH, Hartman DE, Vishwanat B. Orofacial motor control impairment in Parkinson's disease. Neurology 1996;47:340 [RETRACTION].

8. Huth EJ. Repetitive and divided publications. In: Jones AH, McLellan F, eds. Ethical issues in biomedical publication. Baltimore: The Johns Hopkins University Press, 2000:112-136. 


\title{
Neurology
}

\author{
Scientific misconduct and breach of publication ethics \\ Robert B. Daroff and Robert C. Griggs \\ Neurology 2004;62;352-353 \\ DOI 10.1212/WNL.62.3.352
}

\section{This information is current as of February 9, 2004}

\section{Updated Information \&} Services

\section{References}

\section{Citations}

Permissions \& Licensing

Reprints including high resolution figures, can be found at: http://n.neurology.org/content/62/3/352.full

This article cites 3 articles, 0 of which you can access for free at: http://n.neurology.org/content/62/3/352.full\#ref-list-1

This article has been cited by 3 HighWire-hosted articles: http://n.neurology.org/content/62/3/352.full\#\#otherarticles

Information about reproducing this article in parts (figures,tables) or in its entirety can be found online at:

http://www.neurology.org/about/about_the_journal\#permissions

Information about ordering reprints can be found online:

http://n.neurology.org/subscribers/advertise

Neurology ${ }^{\circledR}$ is the official journal of the American Academy of Neurology. Published continuously since 1951, it is now a weekly with 48 issues per year. Copyright . All rights reserved. Print ISSN: 0028-3878. Online ISSN: 1526-632X.

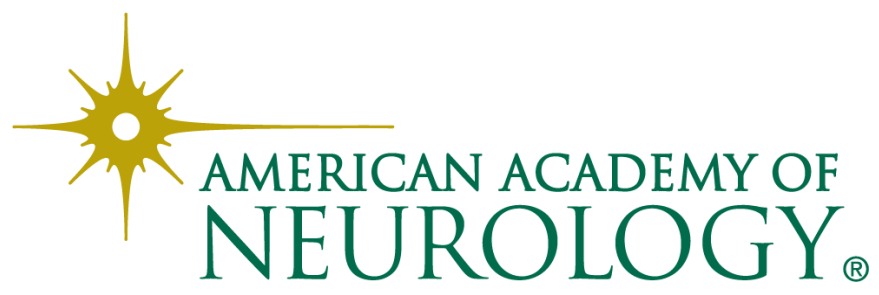

